\title{
Menu Design For Pregnant Women Diet For Stunting Prevention Using Genetic Algorithm
}

\author{
Hermawan \\ Department of Computer Science \\ Universtitas Pakuan Bogor \\ J1. Ciheuleut No.1 Kota Bogor \\ hermawan.taher@unpak.ac.id \\ Reno Cahyo Hutomo \\ Department of Computer Science \\ Universtitas Pakuan Bogor \\ Jl. Ciheuleut No.1 Kota Bogor \\ renocahyohutomo98@gmail.com \\ Sufiatul Maryana \\ Department of Computer Science \\ Universtitas Pakuan Bogor \\ Jl. Ciheuleut No.1 Kota Bogor \\ sufiatul.maryana@unpak.ac.id
}

Mutiara Prihatini

Center for Biomedical Research and Development and Basic Health Technology mutiara.gizi@gmail.com

\begin{abstract}
Indonesia is one of the countries that is still experiencing stunting problems and it is estimated that there will be an increase due to the Covid 19 pandemic. Stunting is an obstacle to growth in children, one of which is the lack of balanced nutritional intake during pregnancy. A pregnant woman's diet should contain macro nutrients, carbohydrates, proteins and fats as well as micronutrients such as folic acid, iron and zinc. Folic acid is believed to be a micro nutrient for preventing stunting. Genetic algorithms are used to design the composition of food by computational processes. In this study, food ingredients are converted into chromosomes with real code chromosome representations. In the Crossover and Mutation processes using the One-Cut Point Crossover and Reciprocal Exchange methods and the best selection process is used. The output is a recommendation of food ingredients with three meals a day, namely breakfast, lunch and dinner. Based on the results of testing the application to practice at community health centers, it produces an average percentage error of $0.7 \%$ energy needs, $3.8 \%$ carbohydrates, $9.7 \%$ protein, $12.5 \%$ fat, $0.5 \%$ folic acid, $15.5 \%$ iron and $17.6 \%$ zinc. Overall, the validation test using statistics at the accuracy level of $95 \%$ states that the genetic algorithm results are not significant for the practice at the public health center.
\end{abstract}

\section{Keywords}

Stunting, Pregnant Women Diet, Folic Acid, Genetic Algorithm

\section{Introduction}

The UNICEF Indonesia Institute reminded that without timely action, the number of malnourished children (wasting) is expected to increase by $15 \%$ (or around 7 million) worldwide in the first year of the Covid 19 Pandemic. The Ministry of Health itself noted that Indonesia is one of the a country with three problems related 
to nutrition, namely stunting, wasting and obesity. A case study of under-five nutrition in 34 provinces in Indonesia in 2019 shows that the stunting rate reaches 27.67\% (Ramanditha, 2020) as shown in Figure 1.

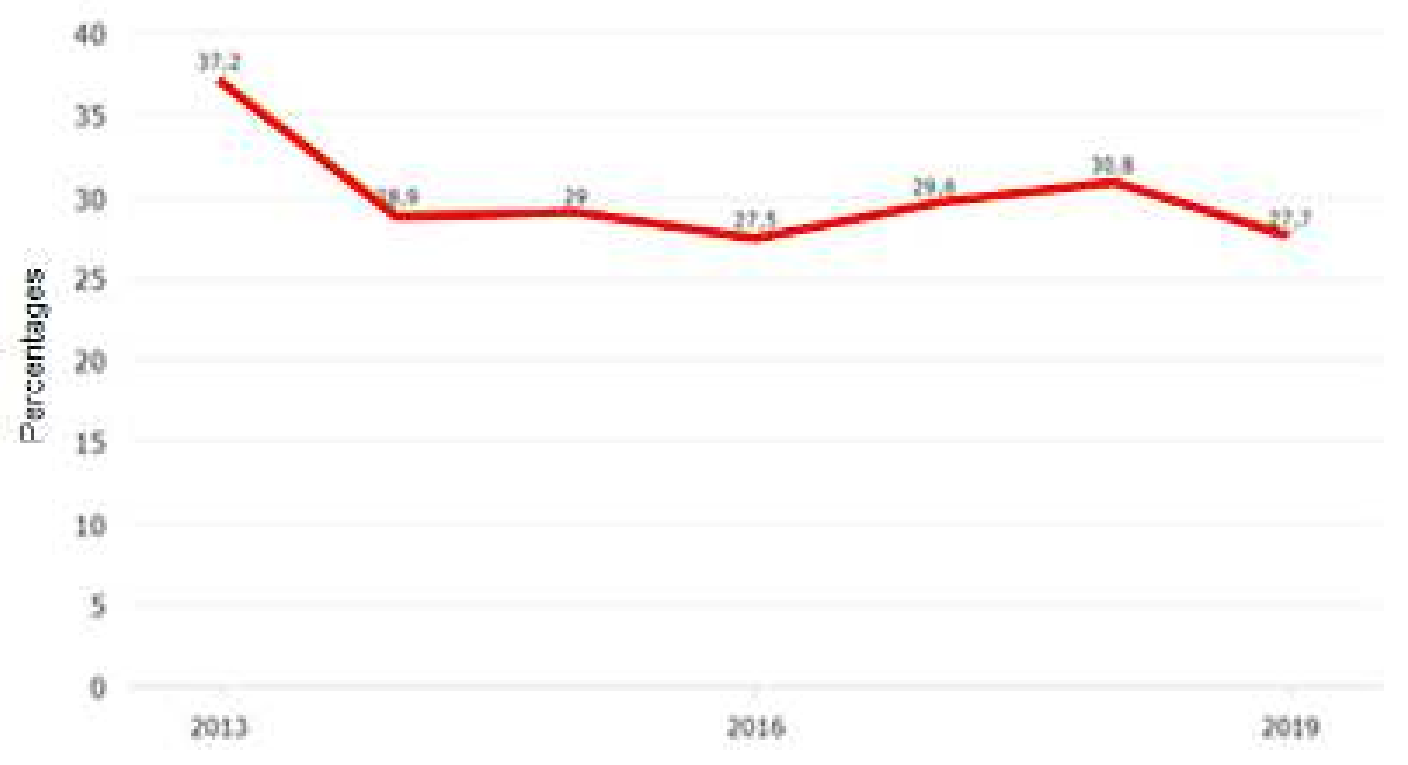

Figure 1. Prevalence of children under five with stunting in Indonesia 2013-2019 (Ramandhita, 2020)

Stunting is a condition of failure to thrive in children under five years of age as a result of chronic malnutrition so that children are too short for their age (UNICEF, 2010). Malnutrition occurs since the baby is in the womb and in the early days after the baby is born. However, the condition of stunting only appears after the baby is 2 years old. Short (stunted) and very short (severely stunted) toddlers are toddlers with body length (PB / $\mathrm{U}$ ) or height (TB / U) according to their age compared to WHO standard standards.

According to regulation of Indonesian Ministry of Health No. 97 of 2014 the factors that aggravate the condition of pregnant women are too young, too old, too frequent childbirths, and too close the birth distance. Pregnant mothers who are too young (under 20 years) are at risk of giving birth to low birth weight babies (LBW). LBW babies account for about $20 \%$ of the incidence of stunting. In the Republic of Indonesia Minister of Health Regulation No. 41 of 2014 pregnant women need more nutrients than those who are not pregnant. During pregnancy, a mother must increase the amount and type of food eaten to meet the growing needs of the baby and the needs of the mother who is carrying a baby and to produce breast milk.

Research conducted by Salman et al. (2017) noted that there was no real relationship between a mother's knowledge of nutrition and stunting. Research by Sutarto et al. (2018) states that stunting is caused by many factors, not only nutritional problems, even so the study still recommends fulfilling pregnant women nutrition as a prevention of stunting. Research by Alfarizi et al (2019) found clear evidence that the nutritional status of pregnant women shows stunting conditions in infants aged 6-59 months. Handayani et al (2020) have used genetic algorithm methods to design pregnant food menus, but this research has not paid attention to the special needs of preventing stunting. Thus, this study was conducted with the aim of designing an improved diet for pregnant women as an effort to prevent stunting.

\section{Methodology}

In general, the research methodology is divided into two stages, first is determining the minimum nutritional requirements for pregnant women from the perspective of preventing stunting, second is determining the composition of the diet for these pregnant women. The first stage uses an energy demand approach for pregnant women which can be done in three steps, namely calculating the Basal Energy Expenditure (BEE), Total Energy Expenditure (TEE) and additional energy according to gestational age, while the second stage uses the Genetic Algorithm. In general, the research stages are shown in Figure 2a.

In designing the genetic algorithm, several stages are carried out, namely initialization of user data parameters and genetic algorithm parameters, initial population formation by chromosome initialization, 
crossover, mutation, fitness evaluation and selection. The stages of designing a genetic algorithm are presented in Figure 2b.

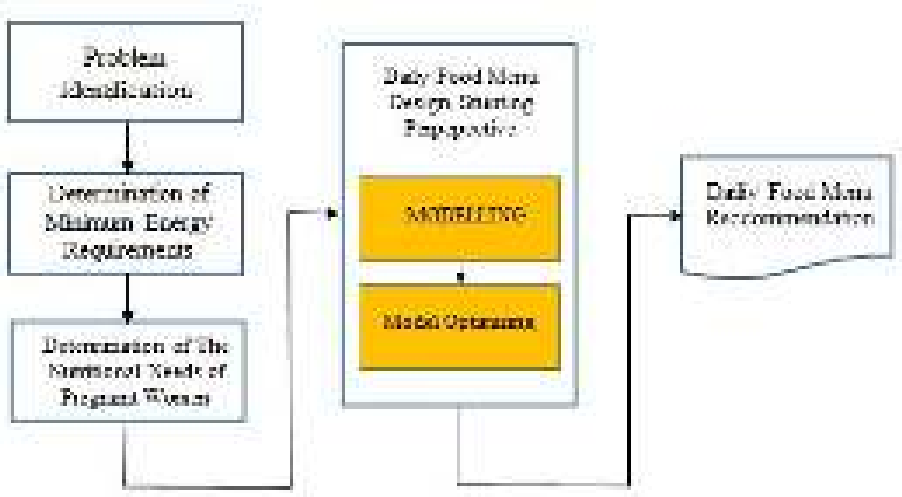

2a. General Research Design

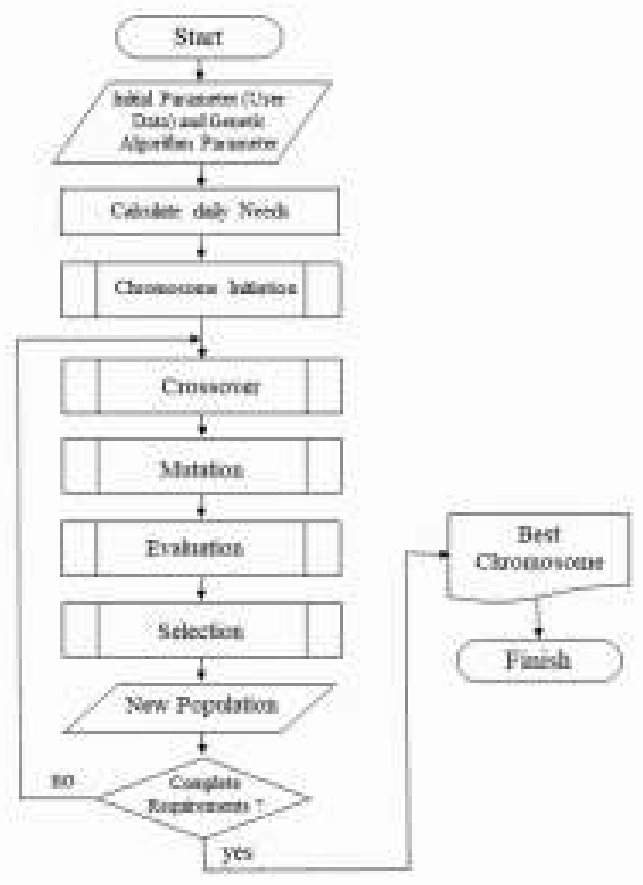

2b. Flowchart of the genetic algorithm method

Figure 2. Research Methodology

\section{Result and Discussion}

\subsection{Result}

3.1.1. Calculation of Nutritional Requirements for Pregnant Women

Basal Energy Expenditure (BEE) is the minimum amount of energy the body needs when the body is in a resting state to maintain and maintain various vital body functions, such as heart work, respiratory activity, hormonal activity, muscle activity. To calculate the Basal Energy Expenditure (BEE), the Harris-Benedict equation can be used as shown in Equation 1 as follows:

$$
B E E=655+(9,6 \times \text { weight }(\mathrm{kg}))+(1,8 \times \text { height }(\mathrm{cm}))-(4,7 \times \text { age }(\text { year }))
$$

Total Energy Expenditure (TEE) is the development of a calculation formula for energy needs with an Activity Multiplier or activity factor, namely the multipliers used to find the total energy spent in a day depending on the level of activity, which is known as Total Energy Expenditure (TEE). To calculate TEE in healthy people, the BEE must be multiplied by 1.3 and the Activity Factor so that it can be formulated

$$
T E E=B E E \times \text { Activity Factor x } 1.3
$$

The activity factors are shown in Table 1.

Table 1. Activity Factors

\section{Activity Factor}

\section{Activities of Pregmant Woman}

Rest 


\begin{tabular}{cl}
\hline 1,2 & There is no meaningful activity \\
1,3 & Housewives, Store Clerks, Office Clerks \\
1,4 & Students, Teacher, Bank Officer \\
\hline
\end{tabular}

(Almatsier, 2010)

Pregnant women need to get additional energy and nutrition aimed at supporting the growth and development of the fetus in the womb, the amount of which is shown in Table 2 as follows:

Table 2. Additional nutritional requirements according to gestational age

\begin{tabular}{lccc}
\hline \multicolumn{1}{c}{ Gestational Age } & $0-12$ & $13-27$ & $28-40$ \\
Additonal Carbohydrates & Weeks & Weeks & Weeks \\
Additional Protein & $25 \mathrm{~g}$ & $40 \mathrm{~g}$ & $40 \mathrm{~g}$ \\
Additional Lipid & $20 \mathrm{~g}$ & $20 \mathrm{~g}$ & $20 \mathrm{~g}$ \\
Additional Folic Acid & $6 \mathrm{~g}$ & $10 \mathrm{~g}$ & $10 \mathrm{~g}$ \\
Additional Iron & $200 \mu \mathrm{g}$ & $200 \mu \mathrm{g}$ & $200 \mu \mathrm{g}$ \\
Additional Zinc & $0 \mathrm{mg}$ & $9 \mathrm{mg}$ & $13 \mathrm{mg}$ \\
\hline
\end{tabular}

(Indonesian Ministry of Health, 2013)

After getting the total daily energy value, the next step is to calculate the macro nutritional needs using the following series of equations, according to the Regulation of the Minister of Health (Permenkes) RI No. 75 of 2013 concerning the Recommended Nutritional Adequacy Rate as follows:

Carbohydrate $=1 / 4 \times(60 \% \times$ TEE $)+$ Additional Carbohydrates according to gestational age

Protein $\quad=1 / 4 \times(15 \% \times$ TEE $)+$ Additional Protein according to gestational age

Lipid $\quad=1 / 9 \times(25 \% \times$ TEE $)+$ Additional Lipid according to gestational age

Folic Acid $=400+$ Additional Folic Acid according to gestational age

Iron $\quad=26+$ Additional Iron according to gestational age

Zinc $\quad=10+$ Additional Zinc according to gestational age

As a trial, this study used data on pregnant women with various variables, such as age, weight, height, gestational age, and dominant daily activities. Next Calculation of the daily needs of pregnant women before and after pregnancy is carried out with the calculation results as follows:

Table 3. Application trials

\section{General Information}

\begin{tabular}{|c|c|c|c|}
\hline Age & $: 22$ & years & \\
\hline Weight & $: 65$ & $\mathrm{~kg}$ & \\
\hline High & $: 165$ & $\mathrm{~cm}$ & \\
\hline Gestational Age & $: 5$ & minggu & \\
\hline Main Daily Activities & : Clerk & & \\
\hline \multicolumn{4}{|c|}{ Requirements } \\
\hline Diet Requirements & Unit & Before pregnancy & After pregnancy \\
\hline Energy & KKal & 2297,3 & 2297,3 \\
\hline Carbohydrates & gram & 344,6 & 369,6 \\
\hline Protein & gram & 86,1 & 106,1 \\
\hline Lipid & gram & 63,8 & 69,8 \\
\hline Folic Acid & $\mu$ gram & 400 & 600 \\
\hline Iron & miligram & 26 & 26 \\
\hline Zinc & miligram & 10 & 12 \\
\hline
\end{tabular}

3.1.2. Genetic Algorithm Computation

Genetic Algorithm Parameters 
In this study, the average fitness of each generation is used as an indicator, so the following parameters are used:
PopSize
$=30$
Generation
$=5$
Cr (Crossover Rate)
$=0,95$
$\mathrm{Mr}$ (Mutation Rate)
$=0,01$

Initialization of chromosomes gives rise to a new random set of solutions consisting of a number of chromosomes and placed in reservoirs called populations. Chromosome initialization is carried out randomly, however, we must pay attention to the solution domain and the existing problems. In this study, a population size of 30 was determined.

Crossover

The crossover method used in this study is the One-Cut Point Crossover which is carried out by selecting two random parents from individuals, determining the intersection point randomly, and exchanging genes in chromosomes that are limited by the intersection points.

\section{Mutation}

The mutation method used in this study is reciprocal exchange mutation which is done by choosing one parent randomly, choosing two points randomly but with the same conditions and exchanging each point as shown in Figure 3 as follows:

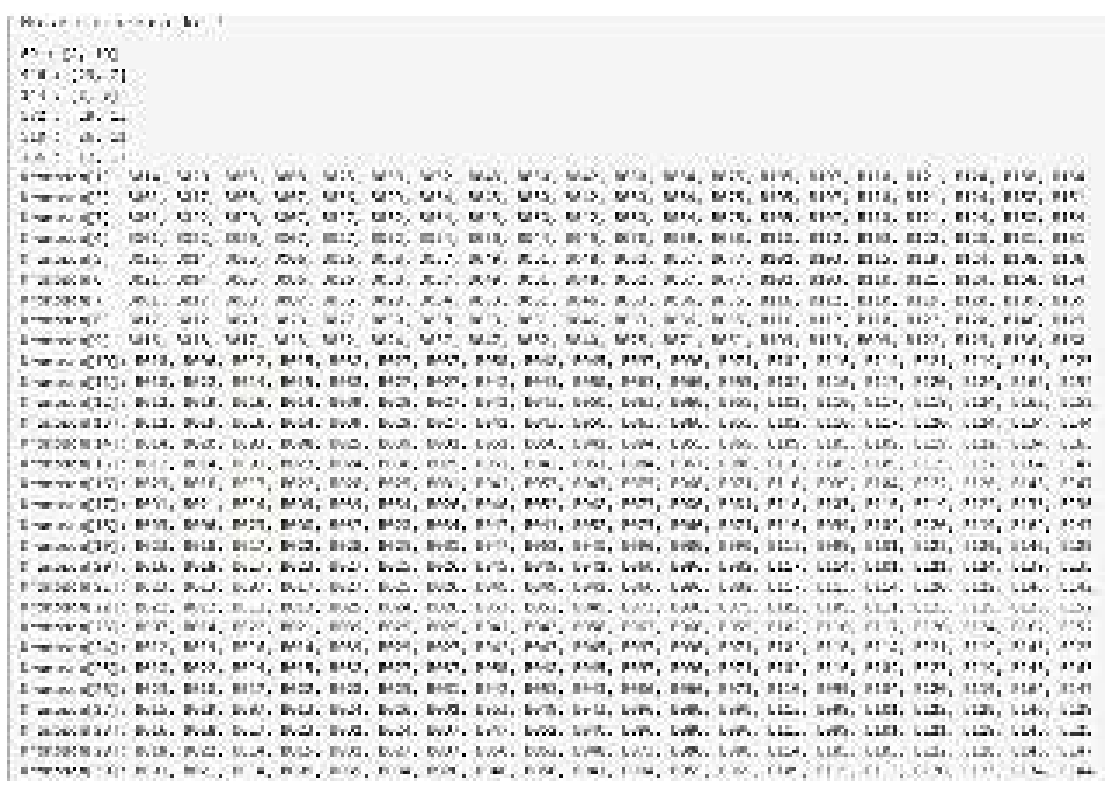

Figure 3. Chromosome Mutation Results

\section{Evaluation}

The fitness function is used to measure the level of goodness or suitability (fitness) of a solution with the solution being sought. The fitness function can be directly related to the objective function, or it can be slightly modified to the objective function. The number of solutions generated in the population will be evaluated using the fitness function. In this study, to calculate the fitness value it has been adjusted using Equation as follows:

$$
f=\frac{1}{\left[\left|\left(r-\sum a\right)\right|+\left|\left(k-\sum b\right)\right|+\left|\left(p-\sum c\right)\right|+\left|\left(l-\sum d\right)\right|+\mid\left(a f-\sum e|+|\left(z b-\sum f\right)|+|\left(s-\sum g\right) \mid\right]+\right.\text { small number }}
$$

Notes :

$r \quad=$ Daily Energy Requirements (Calculation result).

$k=$ Carbohydrates needs in one day (Calculation result).

$p=$ Protein needs in one day (Calculation result).

$l=$ Lipid needs in one day (Calculation result).

af $=$ Folic Acid needs in one day (Calculation result). 
$z b=$ Iron needs in one day (Calculation result).

$s \quad=$ Zinc needs in one day (Calculation result)

$a=$ Energy content of food ingredients in one day

$b \quad$ Carbohydrates of food ingredients in one day

c $\quad$ Protein of food ingredients in one day

$d \quad=$ Lipid of food ingredients in one day

$e \quad=$ Folic acid contents of food ingredients in one day

$f \quad=$ Iron contents of food ingredients in one day

$g \quad=$ Zinc contents of food ingredients in one day small number $=$ Numbers to avoid with division 0 .

Following are the results of the calculation of the fitness value of each gene on the chromosome which can be seen in Figure 4 as follows

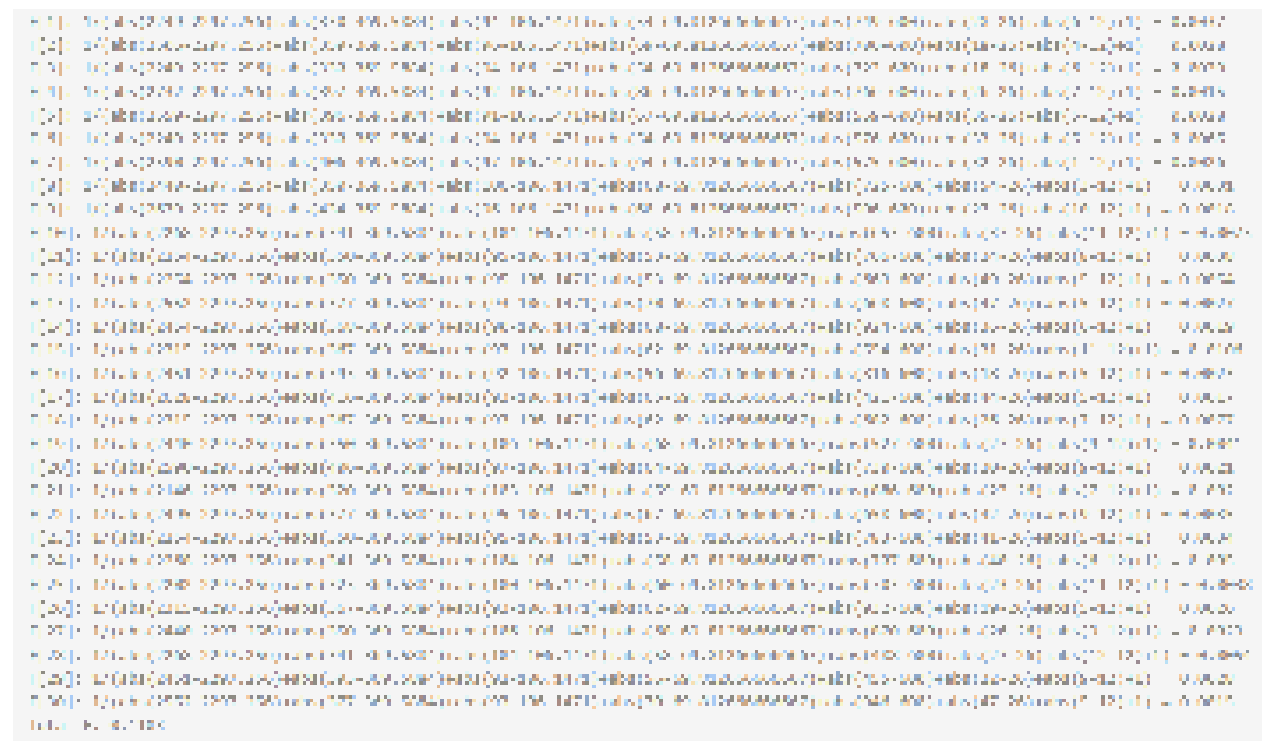

Figure 4. Chromosome Fitness Values

\section{Selection}

The selection used in this study is Elitism Selection, which is a selection method in which one or more chromosomes with the highest fitness value are copied directly to the next generation without experiencing manipulation which can be seen in Figure 5 as follows

\begin{tabular}{|c|c|}
\hline \multicolumn{2}{|c|}{ 1\% Gengationsiglection } \\
\hline$k[1]-k[4]$ & \\
\hline$K\{2]=K[1]$ & \\
\hline$k[3]=k[18]$ & $\begin{array}{l}k[17]-k[27] \\
k[18]-K[13]\end{array}$ \\
\hline$K[4]=K[1]$ & $k[19]-K[14]$ \\
\hline$K[5]-K[18]$ & $k[2 \theta]-k[5]$ \\
\hline$k[6]=k[15]$ & $K[21]=K(16]$ \\
\hline$k[7]=k[1]$ & $k[22]-K[30]$ \\
\hline$k[B]-k[26]$ & $k[23)-k[22]$ \\
\hline$K\{9]-K[5]$ & $x[24]-x[23]$ \\
\hline$K\{10]-K[11]$ & $k(25)=k[2]$ \\
\hline$k(11)=k(7)$ & $K(26)-K(14)$ \\
\hline$K[22]-K(20]$ & $k[27]-k[25]$ \\
\hline$x[13]-k[28]$ & $K(28]-K[5]$ \\
\hline$K[14]-K[4]$ & $k[29]-k\{7]$ \\
\hline$K[15]-K(27]$ & $K[30] \cdot K[17]$ \\
\hline
\end{tabular}


Figure 5. Chromosome Selection Results

\section{Population Change}

If the parameters of the Genetic Algorithm have been met, the process can be stopped. Then the chromosomes that have the best fitness value will be selected, the chromosomes will be converted into a list of food ingredients in the database. The following chromosomes with the best fitness values can be seen in Figure 6.

After all the genetic algorithm processes have been carried out, there will be a final result in the form of 1 chromosome value that matches / approaches the needs of pregnant women in accordance with predetermined rules. After selecting the best chromosomes through a process according to predetermined parameters, the chromosomes will be converted into an index list of foodstuffs in the database.

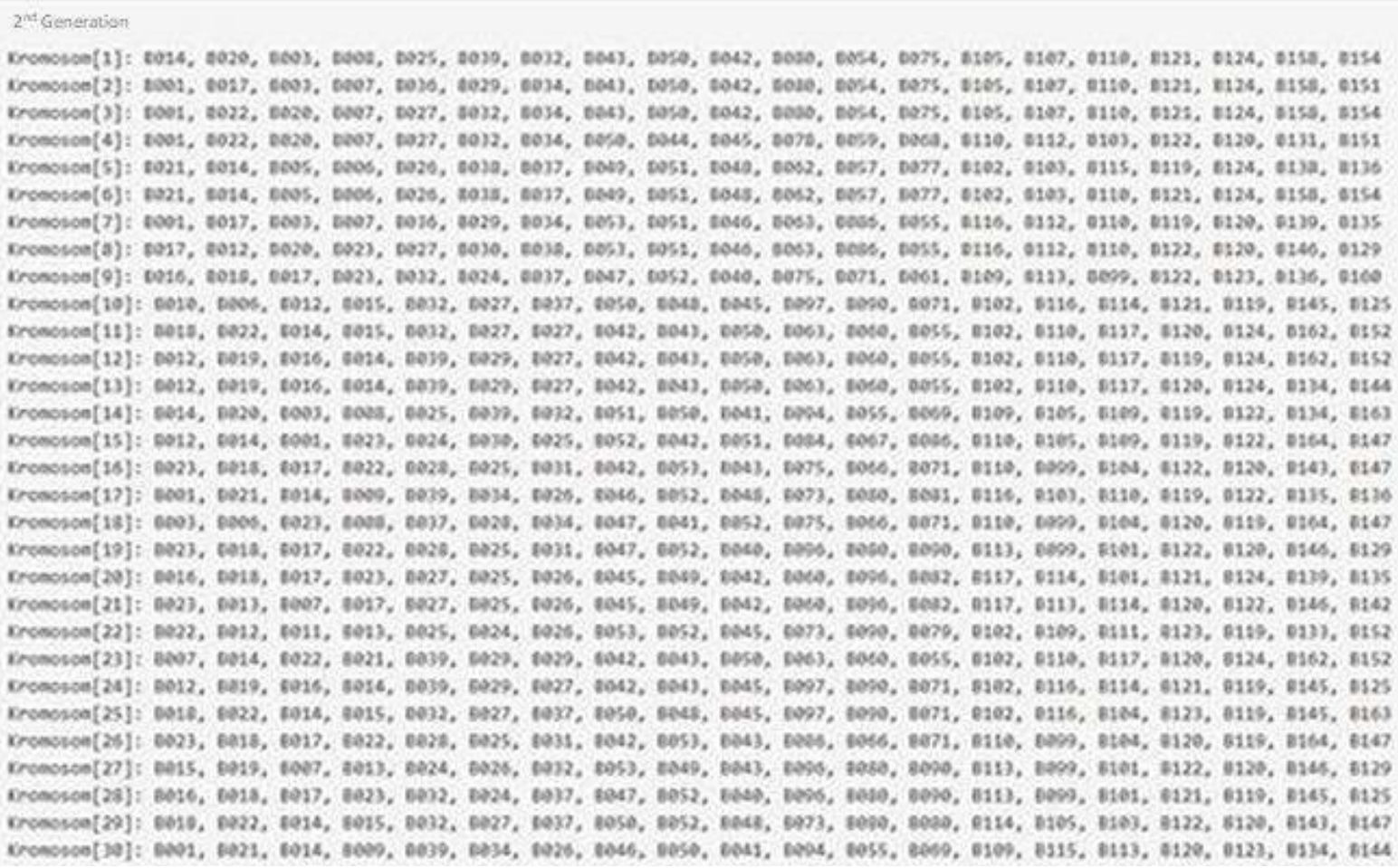

Figure 6. New Population Computation Results

\subsection{Discussion}

This study included folic acid micronutrients in one of the parameters as an effort to supplement pregnant women nutrition for stunting prevention. Astriningrum et al (2017) include folic acid as one of the micro nutrients in the intake of pregnant women for the prevention of anemia which is commonly experienced in pregnancy. Natural Tube Defects (NTD) in infants can also be caused by folic acid deficiency (Partearroy et al., 2017). According to an article entitled Important Guidelines for Preventing Stunting from Pregnancy (Joseph, 2017), preventing stunting can be done early on since pregnancy. The key is to increase the nutritional intake of pregnant women with good quality food. Folic Acid, Iron and Zinc are important nutrients that pregnant women must fulfill to prevent anemia and maintain optimal fetal growth in other words to prevent stunting. Research by Nizar et al (2020) recommends zinc and folic acid supplements for pregnant women to prevent stunting.

The need for folic acid in the system is designed with a value of $600 \mathrm{ug}$ per day, according to the Harvard recommendation (2020). Under normal circumstances, the body needs 50 micrograms of folic acid every day. If the body absorbs less than 50 micrograms of folic acid in a day, then in the next four months folic acid deficiency can occur. The need for folic acid will increase during pregnancy, reaching 800 micrograms to $1 \mathrm{mg}$ per day (Moore et al, 2015). 
The genetic algorithm process was tested to obtain the best ONE chromosome value with the best fitness value as follows:

Best Chromosome $\quad$ B019, B023,
B036, B037,
B042, B049,
B074, B100,
B123, B122, B1

Best Fitness

: 0.02065

Based on the chromosomes with the best fitness values, then the chromosome value values are converted into the list of foodstuffs in the database resulting in an example menu design as Table 4. Of course, rice as a source of carbohydrates and staple food for Indonesians can be included as the main alternative.

The best sources of folic acid in natural foods are legumes such as red beans, green beans, peas, peanuts and a number of other cereals. Harvard (2020) notes some good sources of folic acid including green vegetables such as spinach, lettuce, asparagus, broccoli, a number of cereals, seafood, sunflower seeds, eggs, and liver.

Table 4. Design of diet for pregnant women for prevention of stunting

\begin{tabular}{lc}
\hline \multicolumn{1}{c}{ Meals Schedule } & Food Recommendations \\
Breakfast & Sago flour, Cheese, Dark Chocolate, Taro leaves, \\
Grape, Milk, Pastels \\
Lunch \\
Macaroni, Wheat Bread, Red Snapper, Red Beans, \\
Chives, Guava \\
Wheat Flour, Fresh Shrimp, Mushrooms, "Katuk" \\
Leaves, Cow's Milk, "Fried Getuk"
\end{tabular}

Application testing was carried out on 40 pregnant women with various variable values, such as daily activities, gestational age, height, weight and age of pregnant women. Then a comparison is made between the results of calculations manually and the results of calculations using the system to the value of the content in food ingredients obtained from the genetic algorithm process. Tests conducted on pregnant women to determine their energy needs, macro nutritional needs which include calories, carbohydrates, protein, and fats as well as micronutrient needs including folic acid, iron and zinc by entering data from public health service and interviews pregnant mother. Fulfilling the needs of energy, macro nutrients and micronutrients with a list of food ingredients produced from the genetic algorithm process has an error value compared to manual calculations as shown in Table 5.

Table 5. Trial comparison of GA calculations against which recommendations from the Public Health Center

\begin{tabular}{|c|c|c|c|c|c|c|c|}
\hline No & $\begin{array}{l}\text { Energy } \\
\text { (Kcal) }\end{array}$ & $\begin{array}{c}\text { Carbohydrates } \\
\text { (gram) }\end{array}$ & $\begin{array}{l}\text { Protein } \\
\text { (gram) }\end{array}$ & $\begin{array}{l}\text { Lipid } \\
\text { (gram) }\end{array}$ & $\begin{array}{l}\text { Folic Acid } \\
\text { (microgram) }\end{array}$ & $\begin{array}{c}\text { Iron } \\
\text { (milligram) }\end{array}$ & $\begin{array}{c}\text { Zinc } \\
\text { (milligram) }\end{array}$ \\
\hline \multicolumn{8}{|c|}{ Manual Calculation from the Public Health Center } \\
\hline 1 & 2231 & 359,6 & 103,7 & 68 & 600 & 39 & 12 \\
\hline 2 & 2268,2 & 365,2 & 105,1 & 69 & 600 & 26 & 12 \\
\hline 3 & 2105,8 & 340,9 & 99 & 64,5 & 600 & 35 & 14 \\
\hline $\begin{array}{l}\ldots \\
40\end{array}$ & $\begin{array}{c}\cdots \\
2301,5\end{array}$ & 370,2 & 106,3 & 69,9 & 600 & 26 & $\cdots$ \\
\hline \multicolumn{8}{|c|}{ Genetic Algorithm Computation } \\
\hline 1 & 2228 & 328 & 95 & 53 & 596 & 36 & 10 \\
\hline 2 & 2271 & 351 & 95 & 62 & 589 & 21 & 9 \\
\hline 3 & 2125 & 323 & 104 & 59 & 600 & 29 & 13 \\
\hline$\ldots$ & $\ldots$ & $\ldots$ & .. & $\cdots$ & $\ldots$ & $\ldots$ & $\ldots$ \\
\hline 40 & 2315 & 367 & 93 & 62 & 596 & 26 & 9 \\
\hline \multicolumn{8}{|c|}{ Deviation } \\
\hline 1 & 0,001 & 0,088 & 0,084 & 0,221 & 0,007 & 0,077 & 0,167 \\
\hline 2 & 0,001 & 0,039 & 0,096 & 0,101 & 0,018 & 0,192 & 0,250 \\
\hline 3 & 0,009 & 0,053 & 0,051 & 0,085 & 0,000 & 0,171 & 0,071 \\
\hline$\ldots$ & & & & & & & \\
\hline
\end{tabular}




\begin{tabular}{cccccccc}
\hline 40 & 0,006 & 0,009 & 0,125 & 0,113 & 0,007 & 0,000 & 0,250 \\
Average & $\mathbf{0 , 0 0 7}$ & $\mathbf{0 , 0 3 8}$ & $\mathbf{0 , 0 9 7}$ & $\mathbf{0 , 1 2 5}$ & $\mathbf{0 , 0 0 5}$ & $\mathbf{0 , 1 5 3}$ & $\mathbf{0 , 1 7 6}$ \\
\hline
\end{tabular}

Note : Daily requirements

Validation test using statistics From the table above it can be seen that the Mean Percentage Error (MPE) is $(0.7 \%)$ for energy needs, $(3.8 \%)$ for carbohydrate needs, $(9.7 \%)$ for protein needs, $(12.5 \%)$ for fat needs, $(0.5 \%)$ for folic acid needs, $(15.3 \%)$ for iron needs and $(17.6 \%)$ for zinc needs. The statistical trial shows that for the accuracy level of $95 \%$, all the results of the composition of food ingredients are calculated as "not significantly different" from the calculation of practice at the Public Health Services.

\section{Conclussion}

One of the efforts to prevent stunting in Indonesia can be done through improving nutrition and diet in pregnant women. In determining a good diet, each diet must meet the macro nutritional composition in the form of carbohydrates, proteins and fats as well as micro nutrients such as folic acid, iron and zinc which can prevent stunting. Folic acid has an important role in preventing stunting.

From the results of the research that has been done, it can be concluded that the Genetic Algorithm method can be used to design a list of foodstuffs for pregnant women in an effort to prevent stunting at birth. With predetermined method parameters, this application is able to produce recommendations for a list of food menus in a day that have been adjusted to the basic energy needs of pregnant women.

The Genetic Algorithm parameters defined are Pop Size of 30, Crossover Rate of 0.95, Mutation Rate of 0.01 , the determination of these parameters is based on the fact that the average fitness of each generation is used as a calculation indicator and uses various data variables from pregnant women. Elitism selection is used because it ensures that the best individuals will always pass to the next stage.

The trial was carried out by taking data samples from pregnant women from the Public Health Service recommended by the Bogor City Health Official. Data for pregnant women are first selected so that data is suitable for application needs. The number of data that has been tested is 40 with various variables depending on the condition of the pregnant woman, the variables used are various such as daily activities, gestational age, height and weight of the pregnant woman.

Based on the results of application trials using the Mean Percentage Error (MPE) method along with the accuracy for an average error of $0.7 \%$ for energy needs, $3.8 \%$ for carbohydrate needs, $9.7 \%$ for needs Protein, $12.5 \%$ for lipid needs, $0.5 \%$ for folic acid needs, $15.3 \%$ for iron needs and $17.6 \%$ for zinc needs. The validation test using statistics shows that for the accuracy level of $95 \%$, all the results of the composition of food ingredients are calculated as "not significantly different" from the calculation of practice at the Public Health Services.

\section{Acknowledgements}

Thanks to the Computer Science Department, Universitas Pakuan Bogor, the Center for Biomedical Research and Development and Basic Health Technology, the Indonesian Ministry of Health and the Bogor City Health Office for providing research data support.

\section{References}

Aguayo, V.M. and P. Menon. 2016. Stop stunting: improving child feeding, women's nutrition and household sanitation in South Asia. Maternal \& Child Nutrition published by JohnWiley \& Sons LtdMaternal \& Child Nutrition (2016), 12 (Suppl. 1), pp. 3-11

Alfarisi, R. Y. Nurmalasari, and S. Nabilla. 2019. Status Gizi Ibu Hamil Dapat Menyebabkan Kejadian Stunting Pada Balita. JURNAL KEBIDANAN Vol 5, No 3, Juli 2019 : 271-278

Almatsier, S. 2010. Penuntun Diet Instalasi Gizi Perjan RS. Dr. Cipto Mangunkusumo dan Asosiasi Dietisien Indonesia. Jakarta: Gramedia.

Ariati, N.N., A. Fetria, I. A. E. Padmiari, A.A.P. Purnamawati, P. P. Sri Sugiani, and N.N. Suarni. 2018. Description of nutritional status and the incidence of stunting children in early childhood education programs in Bali-Indonesia. Bali Med J 2018; 7(3): 723-726 | doi: 10.15562/bmj.v7i3.1219

Asri, N. D., Cholissodin, I. \& Ratnawati, D.E. 2018. Optimasi Asupan Makanan Harian Ibu Hamil Penderita Hipertensi Menggunakan Algoritme Genetika. Jurnal Pengembangan Teknologi Informasi dan Ilmu Komputer, Volume 2, pp. 2892-2901. Malang: Universitas Brawijaya. 
Astriningrum, E.P., Hardinsyah, dan N. M. Nurdin. 2017. Intake of folic acid, vitamin B12 and vitamin C among pregnant women in Indonesia based on Total Diet Study. J. Gizi Pangan, Maret 2017, 12(1):3140.

Handayani, N.S. S.Kusumadewi, and E. Fitriyanto. 2020. Food Recommendations for Pregnant Women Using Genetic Algorithms. JUITA: Jurnal Informatika e-ISSN: 2579-8901; Volume 8, Nomor 1, Mei 2020, 4553

Harvard T.H.Chan. 2020. The Nutrition Sources : Folate (Folic Acid) - Vitamin B9. https://www.hsph.harvard.edu/nutritionsource/folic-acid/ accessed 10 Nov 2020

Imam, F., Ratnawati, D. E. \& Kusuma, T S. 2018. Optimasi Komposisi Makanan Untuk Ibu Hamil Menggunakan Hybrid Algoritme Genetika dan Simulated Annealing. Jurnal Pengembangan Teknologi Informasi dan Ilmu Komputer, Volume 2, pp. 4325-4332. Malang: Universitas Brawijaya.

Indonesia Go.Id. 2019. Kementerian Kesehatan Focus pada Pencegahan Stunting. https:/Indonesia.go.id/natasi/Indonesia-dalam-angka/social/kementerian-kesehatan-focus-padapencegahan-stunting. Accessed 11 Nov 2020.

Joseph, N. 2020. Pedoman Penting Mencegah Stunting Sejak Saat Hamil. Website :https://hellosehat.com/kehamilan/kan dungan/mencegah-stunting-pada- anak-sejak-hamil/_[Diakses pada 8 September 2019].

Kementerian Kesehatan RI. 2007. Riset Kesehatan Dasar. Jakarta: Badan Penelitian dan Pengembangan Kesehatan.

Kementerian Kesehatan RI. 2013. Riset Kesehatan Dasar. Badan Penelitian dan Pengambangan Kementeria Kesehatan Republik Indonesia, Jakarta.

Kementerian Kesehatan RI. 2014. Peraturan Menteri Kesehatan Republik Indonesia No. 41 Tahun 2014 tentang Pedoman Gizi Seimbang. Jakarta: Menteri Kesehatan Republik Indonesia.

Kementerian Kesehatan RI. 2014. Peraturan Menteri Kesehatan Republik Indonesia No. 97 Tahun 2014 tentang tentang Pelayanan Kesehatan Masa sebelum Hamil, Masa Hamil, Persalinan, dan Masa sesudah Melahirkan, $\quad$ Penyelenggaraan Pelayanan Kontrasepsi, serta Pelayanan Kesehatan Seksual. Jakarta: Menteri Kesehatan Republik Indonesia.

Kementrian Kesehatan RI. 2017. Tabel Komposisi Pangan Indonesia. Jakarta: Menteri Kesehatan Republik Indonesia.

Margawati,A. dan A.M. Astuti. 2018. Pengetahuan ibu, pola makan dan status gizi pada anak stunting usia 15 tahun di Kelurahan Bangetayu, Kecamatan Genuk, Semarang. Jurnal Gizi Indonesia (The Indonesian Journal of Nutrition), 6 (2), 2018 e-ISSN : 2338-3119, p-ISSN: 1858-4942

Moore A, Mundle W, Connor DO, Ray J, Hof MV., 2015. Pre-conception Folic Acid and Multivitamin Supplementation for the Primary and Secondary Prevention of Neural Tube Defects and Other Folic AcidSensitive Congenital Anomalies. J Obstet Gynaecol Can 2015;37(6):534-549

Nafi'iyah, N. 2015. Sistem Penentuan Keluhan Ibu Hamil dengan Algoritma Genetika. Lamongan: Universitas Islam Lamongan.

Ni’mah, K. and S. R. Nadhiroh. 2015. Faktor Yang Berhubungan Dengan Kejadian Stunting Pada Balita. Media Gizi Indonesia, Vol. 10, No. 1 Januari-Juni 2015: hlm. 13-19

Nisar, Y. V. M. Aguayo, S.M. Billah and M. J. Dibley. 2020. Antenatal Iron-Folic Acid Supplementation Is Associated with Improved Linear Growth and Reduced Risk of Stunting or Severe Stunting in South Asian Children Less than Two Years of Age: A Pooled Analysis from Seven Countries. Nutrients 2020, 12, 2632 , 1-19

Safitri, T. M. M. Cholissodin, I. \& Setiawan, B. D. 2019. Optimasi Kombinasi Bahan Makanan untuk Mencegah Stunting pada Balita dengan menggunakan Algoritme Genetika. Jurnal Pengembangan Teknologi Informasi dan Ilmu Komputer, Volume 3, pp. 7817-7824. Malang: Universitas Brawijaya.

Trihono, Atmarita, Tjandrarini, D. H., Irawati, A., Utami, N. H., Tejayanti,T. \& Nurlinawati, I. 2015. Pendek (Stunting) di Indonesia, Masalah dan Solusinya. Jakarta: Badan Penelitian dan Pengembangan Kesehatan Kementerian Kesehatan Republik Indonesia.

UNICEF. 2010. Stunting Reflects Chronic Undernutrition During The Most Critical Periods Of Growth And Development In Early Life. [Daring] Tersedia di: http://unicef.in/Whatwedo/10/Stuntin g [Diakses pada 20 September 2019].

Partearroyo, T., M. de Lourdes Samaniego-Vaesken, E. Ruiz, J. Olza, J. Aranceta-Bartrina, A. Gil, M. GonzaÂlezGross, R. M. Ortega, L. Serra-Majem, and G. Varela-Moreiras. 2017. Dietary sources and intakes of folates and vitamin B12 in the Spanish population: Findings from the ANIBES study. PLOS ONE. https://doi.org/10.1371/journal.pone.0189230 December 15, 20172 / 19. 1-19

Rahmadhita, K. 2020. Stunting Problems and Prevention. Jurnal Ilmiah Kesehatan Sandi Husada https://akpersandikarsa.e-journal.id/JIKSH Vol 11, No, 1, Juni 2020, pp; 225-229 
Salman, F. Y. Arbie and Y. Humolungo. 2017. Hubungan Pengetahuan Gizi Ibu Dengan Kejadian Stunting Pada Anak Balita Di Desa Buhu Kecamatan Talaga Jaya Kabupaten Gorontalo. Health and Nutritions Journal Volume III / Nomor 1 / 2017. 42-53.

Sumiaty, S.. A. V. Pont, S. Sundari. 2017. Relationship of Mother Factors, Breastfeeding and Stunting Pattern in Central Sulawesi. International Journal of Sciences: Basic and Applied Research (IJSBAR) (2017) Volume 35, No 3, pp 413-420

Sutarto, D. Mayasari, and R. Indriyani. 2018. Stunting, Faktor Resiko dan Pencegahannya. J Agromedicine Volume 5 Nomor 1. 540-545

Wicaksono, F. and T. Harsanti. 2020. Determinants of Stunted Children in Indonesia: A MultilevelAnalysis at the Individual, Household, and Community Levels. Kesmas: National Public Health Journal.2020; 15 (1): 48-53.

Zaif, R.M., M. Wijaya, and D. Hilmanto. 2017. Association Between History of Maternal Nutritional Status during Pregnancy with Growth of Under Five Year Children in Kecamatan Soreang Kabupaten Bandung. JSK, Volume 2 Nomor 3 Maret Tahun 2017. 156-163

\section{Biography / Biographies}

Hermawan is a lecturer at the Department of Computer Science, Universitas Pakuan, Bogor. Obtained a Doctorate degree from Agro-industrial Technology IPB through research on food safety management. His research concentration to date has been the application of computer science to the food and agriculture industries. The author is a member of ASQC, IEOM, ILCan, Agrin, IEEE, Mastan.

Reno Cahyo Hutomo is a young researcher in the field of computer science at the Department of Computer Science, Universitas Pakuan Bogor. Has a research interest in the application of computer science to the food sector.

Sufiatul Maryana is the head of the Information Systems Department at the Vocational School, Universitas Pakuan Bogor. He has a bachelor's and master's degree in computer science. The research concentration concerned is in the field of information systems and has had various publications both nationally and in international journals.

Mutiara Prihatini is a bachelor and master of nutrition science, is a senior researcher at the Center for Research and Development of Biomedical and Basic Health Technology, Ministry of Health of the Republic of Indonesia. He has done a lot of research in the field of nutrition according to his competence. 